\title{
Effect of Inventory Conversion Period on Liquidity of Equity Securities of Companies at Nairobi Securities Exchange
}

\author{
John Murunga Kadima ${ }^{1} \quad$ Dr. Tobius Olweny ${ }^{2} \quad$ Dr. Clive Mukanzi ${ }^{3}$ \\ 1.Phd student: Jomo Kenyatta University of Agriculture and Technology \\ 2.Lecturer:Jomo Kenyatta University of Agriculture and Technology \\ 3.Lecturer: Jomo Kenyatta University of Agriculture and Technology
}

\begin{abstract}
Investors consider Liquidity of assets as an avenue of finances to the organizations. Illiquidity has led most of the listed companies to run insolvent in that considerable managerial obligations in firms fail to be honoured. Liquidity is considered as the capability with which a security could either be sold or bought at securities exchange. Inventory Conversion period, arises from Working Capital elements which is preferred as relevant on determining the level of cash cycle conversion period which is vital for the organization's contractual functions both internally and externally. Inventory Conversion Period is an internal function of the organization that provides in-house financial information that assist investors to make decisions over the existence of a firm and how such a firm can be recognized by external investors who would like to associate themselves with the firm. The objective of the study was to examine the effect of Inventory Conversion Period on Liquidity of Equity Securities of Firms listed at Nairobi Securities Exchange. This study considered target population of the entire listed sixty one firms during the closing of the financial year 2016 and embraced a study period of ten years. The study applied panel data that consisted of secondary information for all companies found from publicized audited financial reports. Census technique was used on entire population of companies since it was comparatively moderate and manageable. This study used Descriptive research design anchored on pragmatism philosophy since the design could depict and describe the situation of the population the way it really was. E-views software was applied for descriptive and inferential statistical analysis and on panel data for regression analysis. Findings on Inventory Conversion Period indicated a positive and significant effect on Liquidity of Equity Securities at Nairobi Securities Exchange. This study embraced for proper management of inventory conversion period since improves on Liquidity of Equity Securities of companies listed at Nairobi Securities Exchange. The study recommended for further research on the Inventory Conversion Period and Liquidity of Equity Securities since it was just but one of components of working capital components, hence results could be different when combined with other independent variables and the regressed on Liquidity of equity securities at the securities exchange market.
\end{abstract}

Keywords: Liquidity, Inventory Conversion Period, Firm Size, Liquidity

DOI: $10.7176 /$ RJFA/11-22-09

Publication date: November $30^{\text {th }} 2020$

\section{Introduction}

Concept of liquidity at the securities exchange market and its determinants vary significantly depending on country's economic level of development and could not be assessed based on a single indicator in all countries. Liquidity in emerging markets is significantly affected by globalization factors and leverage of global financial institutions. According to Karkowska (2015) study on advanced markets of securities, liquidity was determined by financial market drivers and Risk aversion Credit as a measure of global liquidity, more so, credit aggregate was characterized as final link in financial intermediation chain and source of liquidity; hence credit was seen as availability of liquidity in a funding market. In the study by Ciccarelli, Maddaloni and Peydro, (2010), global liquidity measurement was based on common factors in dynamics of large number of quantitative liquidity indicators (including monetary aggregates, domestic and cross border credit aggregates, money market rates and stock market volatility as well retail lending rates). In the study by Amihud, Mendelson and Peterson (2005), liquidity is an exercise of trading a security that just makes it one of key determinants upon which an investor would decide whether to invest or not. Liquidity is regarded as life blood of stock markets and it had vital implications to traders, regulators, stock exchanges and listed companies (Kumar \& Misra, 2015). According to Amihud (2002), liquidity is hard to define, but easy to feel it and hence liquidity consisted of multi-dimension characteristics namely tightness, immediacy, depth, breadth and resiliency that could not be captured in a single measure. Globally acceptable measures of liquidity that could represent most of characteristics continue to be an area of research (O'Hara, 2004).

In the study by Padachi and Carole (2014) on life of a business, firms required liquid assets and cash for daily operations. Such assets are referred to as current assets. Frequent lack of liquidity to meet current obligations on respective due dates was not a welcoming situation and might cause business failure. Poor performance of a given business might be aggravated by heavy borrowing which bring heavy interest burden to the firm. According to Eljelly (2004) on identification of relationship between profitability and liquidity with consideration of cash gap 
on a sample of joint stock companies in Saudi Arabia, results indicated cash gap being a better measure of liquidity than current ratio that was highly associated with profitability. Makori and Jakongo (2013) embraced consideration and noted that with greater relative proportion of liquid assets, the lesser risk of running out of cash, all other things being equal. Essence of current assets was to solve short-term obligations of current liabilities. More so, consideration for management should be to control current assets and current liabilities components in order to have liquidity capability to make an organization to move on. Cornnet (2009) embraced and gave an impression of management employing liquidity ratios to measure how flexible a firm's management could meet short term obligations on maturing hence if a given firm fails to balance current assets and current liabilities, it might be forced into liquidation.

IMF (2010) examined on a link between capital investment flows and growth in global liquidity on emerging markets and found that global liquidity was positively correlated to equity investments. In advanced economies, change in risk appetite and monetary policy affected global liquidity than what happened in emerging markets (Chudik \& Fratzscher, 2011). In the study by Eickmeier, Gambacorta and Hofmann (2014) on understanding global liquidity at a market, liquidity improved by enhanced global credit supply which contributes to financial development. In the study by Stahel (2003) on whether there was a global liquidity factor, global liquidity of individual stocks and their implications for pricing of financial assets in an international framework for a sample from United Kingdom, United States and Japan from 2008 to 2001, conclusion was that individual stock liquidity exhibited itself within countries and industries and co-moves globally.

Liquidity and working capital management in Africa's economy are prone to globalization factors. Global financial crisis leads to downfall of large firms that spill over to multi-national companies with business around the globe. Effects are reflected by company's securities performance at stock exchange markets especially equity securities (Abubakar, Jagongo, Almadi \& Muktar, 2014). African stock markets suffer from problem of low liquidity, as measured by turnover ratio was as low as 0.02 percent in Swaziland and low liquidity meant that it would be harder to support a local market with its own trading system, market analysis, and brokers, because business volume would simply be too low (Yartey \& Adjasi,2007).

Africa being an emerging continent faces global effects on liquidity as well as managerial techniques that affect management of short-term resources that consist of accounts receivables, accounts payables and inventory. Managing of working capital included all aspects of administration of current assets and liabilities which could be the work of strategic managers (Hofmann \& Kotzap, 2010).Strategic managers should be concerned about four elements of working capital management for a company to succeed and maintain the liquidity levels (Arnold, 2008). African markets in general are still thin and illiquid. The thinness and illiquidity of stock markets serve as a big hurdle against financial regionalization of African stock markets that would aid in mobilizing of financial resources in order to fund regional firms and by so doing, the markets would also be injected with more liquidity (Mattes, 2012).

Kenya being an emerging economy, available studies on efficiency of Nairobi Securities Exchange shows weak-form efficiency. For instance a Cross country analysis of capital markets in Africa revealed and had to show emerging capital markets including Kenya were weak-form efficient (Appiah- Kusi \& Menyah, 2003). A number of reasons have been cited to account for inefficiency of Kenyan capital market. Most of all, among them was hitherto manual listing and paper certification on securities exchange market which hindered information flow before total automation. Hence delays in adjusting stock prices to give a reflection for available information on securities market showing effects of over and under valuation of stock prices was experienced. Automation of Nairobi Securities Exchange was premised on belief of improving efficiency (both operational and informational) of securities exchange market. More so installation of Central Depository Systems and automation at Nairobi Securities Exchange was expected to improve operational efficiency (Onyuma, 2009).

Losbichler and Mahmood (2012) referred inventory conversion period as one of the most powerful and least understood driver for supply chain managers to improve a company's cash flow and profitability. More over Corporate Financial literature historically focused most upon long term financial decisions, such as investments, capital structure, dividends or company valuation. Research within short term Financial Management and Working Capital Management was limited. Kumar and Misra (2015) referred to inventory conversion period as a Working Capital Management factor that was very important in maintaining existence, liquidity, solvency and profitability of a firm. According to Bana (2012) acknowledged that while the firm's profitability or accounting profit was an important factor in management's performance, a direct concern for shareholders was wealth maximization and firm value which stock performance showed. Lettan and Ludvigson (2003), Financial Markets were hard to understand, share prices was volatile and hard to predict. Researchers and Market Participants had to devote significant resources into trying to achieve and understand behavior of liquidity of expected stocks and their return.

Since 1990 emerging securities markets did experienced considerable development (Aduda, Masila \& Onsongo, 2012). Kenya being an emerging economy with a securities market still developing, allowed business to be publicly traded or raise additional funds for investment. With liquidity that securities market provided, allowed investors to sell shares of ownership of companies in public market. Since automated trading system was initiated 
in 2006, Kenya was ranked one of best securities market in Africa in terms of equity market performance as concerns liquidity. Due to Globalization effects, liquidity at Nairobi Securities Exchange was prone to cross-border transactions and management of institutions' short term obligations was affected with spillover of liquidity problems emanating from multi-national firms that ended up to other firms in the country (Joshi, Sood, Soans, Denfeld, Mitra \& Harp, 2008).Companies failed and faced liquidity problems because of Working Capital Management techniques (Makori \& Jagongo, 2013).

According to Owalabi and Alu (2012), a firm's liquidity did to a large extent determine profitability. However, liquidity and profitability were not same but were core objectives of a firm. Operation cost results from management of working capital while financing daily activities of a company (Nkwonkwo and Osho, 2010). In the study by Gamze, Ahmet and Emin (2012), main objective of inventory conversion period was to have optimal balance of inventories with respect to other working capital components. Failure to provide sufficient management of working capital components most companies close down and those firms that have relocation capabilities move to other countries with less operational costs. Muhammad and Hassani (2014) embraced managers could increase value by using effective working capital management policies hence effectiveness cushioned escalating operating costs.

Low level of capital market liquidity was a major challenge facing Kenya's securities market, though Nairobi Securities Exchange was generally considered more liquid and active market than most of its East African counterparts in sub-Saharan Africa, by international standards it was small, less liquid and volatile with regard to price and returns. Low liquidity was particularly evident in secondary equity markets. In addition, there was a high incidence of buy and hold particularly among institutional investors, who dominated a market (Capital Markets Authority, 2012). Increasing listing at Nairobi Securities Exchange was always a challenge on stocks being traded. Limited listings have a negative impact on supply of new equities that also affect liquidity. Limited supply of new equities in capital market had restricted use of equity market as a source of financing. In view of past failure to attract new equity, most difficult hurdle for Nairobi Securities Exchange was increasing a number of mediumsized and large family-owned businesses and state-owned companies operating in Kenya and listed at Nairobi Securities Exchange (Nairobi Securities Exchange, 2012).

\section{Statement of the Problem}

Investors consider Liquidity of equity securities at the securities market being vital for success and development of the firm. The easiness with which the assets of the firm can be converted into cash is referred to as liquidity (Ndirangu, 2015). Stakeholders of quoted companies are concerned with how to generate and maintain wealth maximization and firm's value. According to Bratland and Hornbrinck, 2013) on the study of working capital management policies of companies and the stock return of equity securities in Sweden, investors could only succeed if the securities were liquidity at the securities exchange market, otherwise considerably firms would fail and collapse if they could not easily raise capital for success and growth of their businesses, as evidenced by Uchumi Supermarket and Mumias Sugar Company in Kenya (Ndirangu, 2015). Success of a firm relies on management's coordination of internal and external managerial effects of the firm. Inventory Conversion period reflects the internal capabilities of managerial effects of a firm, while liquidity at the securities exchange measures and reflects the external associated managerial effects of the firm at the securities market. Knowledge of roles and drivers of Inventory Conversion Period and drivers of liquidity of securities of companies at securities exchange market is vital; hence firms could be capable to lower risk, prepare for uncertainty and increase performance (Harris, 2005). Inventory Conversion Period being an element of working capital management tools is instrumental in maintaining the existence, liquidity and solvency of an organization (Akash, Khan, Hamid \& Hussain, 2011).

Most scholars, among them, Awad and AI-Ewesat (2012), determined performance of the firms through the relationship between Inventory Conversion periods and accounting liquidity that utilized only internal managerial effects of firm's financial information and found that Inventory Conversion Period impacts on traditional accounting liquidity of the firm. However scholars never linked the firms to external managerial effects information of conditions affecting liquidity in terms of depth, breadth, resilience, immediacy and tightness. Liquidity of securities was affected by macro and micro economic factors and was captured in different ways hence investors should analyze before providing capital to companies. More so, some scholars among them Bratland et al.,(2013) on empirical study of relationship between working capital policies and stock performance in Sweden, found that Inventory Conversion Period could not influence liquidity of securities of companies at securities exchange market at the same rate it affected the accounting liquidity after considering both external and internal managerial effects, hence recommended for further study on the same considering conditions in the organization and at the securities exchange.

This study was therefore designed to address scholarly research gap of earlier scholars for having used only internal organization's managerial information on study of effect of Inventory Conversion Period on accounting liquidity, yet companies were listed. In contrast with earlier studies that limited their scope on determination of liquidity performance indicators by use of firm's internal finance information that was only relevant to internal 
shareholders, this study would investigate the effect of Inventory Conversion Period on liquidity of equity securities of companies at Nairobi Securities Exchange.

\section{Specific Objectives of the Study}

1. To determine Inventory Conversion Period effect on Liquidity of equity securities of companies at Nairobi Securities Exchange.

2. To determine effect of Firm Size on Liquidity of Equity securities of companies at Nairobi Securities Exchange.

\section{Hypotheses of the Study}

The study will adopt the following hypotheses;

$\mathbf{H}_{01}$ : Inventory Conversion Period will not lead to Liquidity of Equity Securities of Companies at Nairobi Securities Exchange.

Ho2: Firm Size will not lead to Liquidity of Equity Securities of Companies at Nairobi Securities Exchange.

\section{LITERATURE REVIEW}

Theoretical Literature Review;

\section{Liquidity Proxies and Characteristics Theory}

In the study by Kumar et al. (2015), an asset was more liquid if it could immediately be realized without loss. Investors might either persist on immediate execution at current bid or ask price or wait to trade at a favorable price, on the same note, Kyle (1985) emphasized that the quoted Ask (offer) price included a premium for immediate buying and the Bid price similarly reflected a concession required for immediate sale. Among the scholars O' Hara (1995) on the study of liquidity and financial stability stipulated that a liquid market had depth, tightness and resilience dimensions. In the study by Bogdan, Baresa and Ivanovi (2012) on measuring liquidity on stock market, free float could serve as a measurement of stock liquidity so long as they excluded the stocks held by strategic stockholders.

In 1987, Bernstein's study on different measures of stock liquidity concluded that liquidity and efficiency were not compatible and hence a liquid market on sensing the arrival of new information, kept noise and sudden price changes at a lower level. On inefficient markets, prices tended to move so fast when new information was received, so liquidity could lead to less efficient markets. In the study by Amihud and Mendelson (1986) on asset pricing and bid -ask price spread, the relationship between Liquidity and cost of capital indicated high liquid markets being more attractive to investors because of easy exit from firm's Ownership and this reduced opportunity cost of capital significantly. In the study by Hui and Heubel (1984) on comparative liquidity advantages among major United States of America stock markets, unsystematic risk represented the illiquidity of stock. Sensitivity of unsystematic risk to changes in the volume executed measured liquidity. Market efficient coefficient was applied as price based measure which stated that price movements were more continuous in liquid markets, even though equilibrium prices were affected by incoming new information.

Saar and Lybek (2002) measured liquidity in financial markets and classified into four categories based on their ability to capture a particular characteristic. Measures were transaction cost measures, volume-based (breadth and depth), equilibrium price based measures (resiliency) and market-impact measures (resiliency and speed of price discovery). In the study by Amihud (2002) on liquidity and securities return, the scholar captured lack of liquidity by dividing daily return by daily dollar volume and expressed the measure as illiquidity that showed the price shock triggered by a unit of dollar volume.

In the study by Amihud (2002) on price impact proxies, the scholar's study captured lack of liquidity by dividing daily return by daily dollar volume, hence such a measurement was called as illiquidity and reflected price shock triggered by a unit of dollar volume. Trizinka et al. (2009) concluded Amihud (2002) measure did a better job than most other measures at capturing liquidity, hence was robust to regime changes such as change in minimum tick size to decimals. Illiquidity was estimated for every share using daily data and impact of each share was weighted by free float rate and market capitalisation. However other measures, for example Amivest measure by Cooper et al. (1985), compared daily returns with daily volume measured in number of shares. However two measures of liquidity for comparison were Amihud and Amivest, hence when constructed in a similar way, methods differed in several aspects. Amihud (2002) used dollar volume while Amivest used share volume. Amihud measure represents illiquidity, while Amivest measure indicates liquidity. Limitation with Amihud measure was that it did not incorporate days without trading, which contained important information for illiquidity. Even if Amivest measure did not suffer from this limitation, it did not include information from days with a zero return.

In the study by PWC (2015) on global financial markets, liquidity was multi-dimensional and could be measured in different ways. In current market environment, changes in market structure and behavior of market participants needed to be considered when interpreting liquidity measures such as Bid-Ask spread. Hence 
dimensions of liquidity were; Immediacy, Depth, Breadth, and Tightness then Multi-Dimensional.

\section{Conservative Policy of Working Capital Management Theory}

In the study by Brian (2009) on working capital, working capital policy was regarded as a set of principles and plans that could establish a course of action for dealing with current assets and current liabilities. Filbeck \& Krueger (2005) embraced that major objective in working capital management was to maintain an optimal balance between working capital components. In other words the main focus was on improvement of the company's flow of funds which is a strategy to maintain an efficient level of current assets and liabilities. According to Brooks (2013), when a firm has larger inflows of cash than outflows but it's not limited to actual in and out-flows but also to timing of cash flow, then it was of great importance to the firm. In the study by Arnold (2008) on working capital policies, there existed three different categories of policies namely; conservative policy, neutral and aggressive policy, hence any management of a firm should be conversant with them.

In the study by Afza and Nazir (2009) on working capital policies, policies could be measured by investment policy, financing policy and a ratio of working capital to total assets, hence investment policy could be used to measure variables of working capital, ascertainment of current assets to total assets ratio could be calculated to determine magnitude level, implying low ratio would mean aggressiveness and high would mean conservative policy. Resulting ratio could reflect a type of investment policy a company could adopt. On applying financing policy, policy uses higher current liabilities and less of long term debts. Computation of current liabilities to total assets ratio could be ascertained to determine magnitude of concerned ratio. Higher ratio meant aggressiveness and hence adoption of aggressive policy would be in place employed by a given firm. On consideration of working capital to total assets ratio, firms use such ratio normally as a measure of company's liquidity. Results indication of low or negative ratio could reflect a firm having difficulties on covering current liabilities. However this could also be an indicator of firm's working capital policy and management. Low or negative ratio could indicate a given firm was operating with a low working capital which would mean that they could be having an efficient working capital management. Utilizing this ratio would be appropriate since it would involve comparing companies of different sizes and more so using total assets could remove issue of size difference.

For the purpose of this study, Conservative and Aggressive policies were employed. However, Brooks (2013) emphasized that Neutral working capital policy was lying in between aggressive and defensive policies. Neutral working capital policy in comparison to the aggressive and defensive was far less explored and there was little previous research about it. However, it could be established that companies that could apply a neutral working capital policy were trying to balance advantages and drawbacks from both policies. This would be done as an attempt to increase profitability of their business. In the study by Belt (2009) on working capital policy, examination on policies was explored in depth on small businesses. More so this scholar concluded that working capital should be expressed in terms of asset liquidity, deferability of sales and composition of financing rather than current assets minus current liabilities. In the Study by Weinraub \& Visscher (1998), an investigation was done to find if there was any significant difference in relative relationship between aggressive and conservative working capital policies between industries. In order to determine conservativeness of firm's working capital policy they applied a ratio of current assets on total assets where a higher ratio would indicate a more conservative approach. The sample they investigated was a total of 216 companies divided into ten different industries during the time period of 1984-1993. In their results they found that it's common that when a company was following an aggressive policy towards working capital assets it is often balanced with a more conservative working capital financial policy. Moreover they also found that there was stability in the relative industry ranking of aggressive/conservative asset policies over time. Scholars concluded by recommending for further studies.

In the study by Brooks (2013) on analysis of working capital management, main objective was to maintain an optimal balance between working capital components as Filbeck \& Krueger (2005) sentiments. Main focus was on improvement of the company's flow of funds which was a policy to maintain an efficient level on both current assets and liabilities. Thus according to this scholar a company with larger inflows of cash than outflows but it was not limited to actual in and out-flows but also to timing of cash flow which was of great importance. In the study by Arnold (2008) on corporate financial management, conservative working capital policy emphasized that the company was having large cash or near cash balances, generous customer credit and high amount of inventories. Adopting this approach could be beneficial for firms that could be working in uncertain environment where they needed extra buffer of inventory in order not to risk opportunity cost of lost sales because of for example stockouts or production stoppages. In the study by Horne and Wachowitz (1998) on fundamentals of finance management, conservativeness meant cost of financing working capital was equivalent to cost of long term fund which was annual average loan multiplied by long term rate of interest. In the study by Panigrahi (2014) on understanding working capital financing strategy, estimated requirement of total funds should be met from long term sources and hence use of short funds should only be restricted to emergencies.

On contrary conservative policy of working capital management was associated to lowering risk and return, hence large amount invested in the current assets increased liquidity (Afza \& Nazir, 2009). In the study by Al- 
Mwala (2012) on impact of working capital management policies on firms' profitability, conservative investment policy had a positive impact on a firm's value and liquidity. In the study by Al-Shubiri and Mohammad (2013) on relationship between cash conversion cycle on financial characteristics of industrial sectors, conservative investment policy placed a greater proportion of capital in liquid assets as opposed to productive assets.

Among scholars, Horne and Wachowitz (1998) expressed conservativeness concept consisting of a reflection of cost to financing working capital being equivalent to cost of long term fund that could be annual average loan multiplied by long term rate of interest. Fixed and part of current assets could be financed by long term funds as permanent and long term sources could be more expensive leading to lower risk return. Raheman and Bluementhal (1994) considered Conservative theory implying relatively high investment in current assets in relation to sales, current assets to sales ratio would be comparatively high and assets and turnover ratio would be low.

Linking up management of working capital and trade- return trade-off, accurate estimates of working capital needs to a firm could be relative and as well have varying effects on liquidity and profitability of a given firm. Given determinants of working capital like technology, production policies, demand conditions and operating efficiency the firm's holding of current assets would take into consideration working capital policy that could move on with conservative or aggressive policy, hence such policies would always involve risks and return tradeoffs ( Nyarige \& Olweny , 2014).

\section{Aggressive Policy of Working Capital Management Theory}

Adopting an aggressive working capital policy meant a firm was working with a low level of current assets as a percentage of the total assets (Panigrahi, 2014). It could also be when a firm adopts a financing decision of having a high amount of current liabilities as a percentage of their total liabilities (Mathuva, 2010). In further studies, Afza and Nazir (2009), examined impact of an aggressive working capital policy had upon firms' liquidity. A study was done on 204 non-financial firms listed at Karachi securities exchange, firms were distributed into 17 various industry sectors and time period was 1998-2005, they used aggressive investment policy and applied a measure which was an extension of an earlier study by Weinraub and Visscher (1998). Furthermore in order to evaluate aggressive working capital policies and financing policies these scholars applied return on assets and Tobin's Q (Total market value of a firm/Total asset). Scholars' study found an aggressive approach could not generate more liquidity. More so, results indicated investors gave more weight into stocks from firms that adopt an aggressive approach toward management of working capital and recommended for further study.

Aggressive policy could be something that could likely take place within companies that were operating in an environment with great certainty over their future cash flows and operations; this enabled them to keep their working capital at low levels (Ndirangu, 2015). Firms would hold minimal stocks of cash and inventories and would push customers to pay early while pushing trade creditors and suppliers hence increasing time interval between receipt and payment for their inputs (Panigrahi, 2014). Aggressive working capital policy was associated with higher risk and return (Arnold, 2008). In the study by Belt (2009) on working capital policy on liquidity in small businesses, risk of aggressive policy was potential inability to meet upcoming short term obligations hence increased risk for failure and bankruptcy.

In the study by Bratland and Hornbrinck (2013) on relationship of working capital policies on securities performance in Sweden, benefits of adopting an aggressive policy was varying between industries and also within industries. In the study by Belt (2009) on working capital policy, emphasis was placed on some industrial characteristics where an aggressive working capital policy could be beneficial; first, above-average profit margins, secondly, current assets that were high proportion of total assets, thirdly high proportions of current liability financing and lastly if there was an above average inventory turnover. So benefits out of the traditional way of looking at an aggressive working capital policy (low working capital) were by gaining higher returns from reduction of costs. Arnold (2008) stated that working capital investments were of great importance for companies' success and could rely much upon having well thought out policies.

In the study by Finnerty (1993) on components of working capital, linking up of working capital management with hedging plan theory implication meant; hedging plan stipulated no long term funds are used to finance short term seasonal needs, hence current assets were equivalent to current liabilities. Such a mild policy matches assets and liabilities to maturities. Current acid test and cash ratios are balance sheet measures that cannot provide detailed and accurate working capital and effectiveness. More so hedging theory is risky as it almost fully utilizes firm's capacity to use short term funds and in emergency situations may be difficult to satisfy short term needs.

According to Arnold (2008) firms employ long term sources to finance fixed assets and permanent current assets and short term funds to finance temporary current assets. Richards and Laughlin (1989); Gentry et al. (1990); Schilling (1996) and Boer (1999) persisted on using ongoing liquidity management hence ongoing liquidity management referred to inflows and outflows of cash through a firm as payment and collection took place over time. In hedging approach, a firm needing to have additional inventories for two months would seek short term funds in two months to match inventory purchase. Limited access to short term working capital sources which included bank financing and suppliers' financing could provide a hindrance to hedging approach. Ross et al. (2003) 
advised that most of time it was reasonable to study working capital management approach in relation to application of funds.

In study by Maria (2015) on working capital policies, a firm with an aggressive working capital policy offered short credit periods to customers, held minimal inventory and had a small amount of cash in hand. Such a policy increased risk of defaulting due to fact that a company might face lack of resources to meet short term liabilities but also give a high return as is associated with high risk. However when a firm initiates aggressive plans to take high risk and more so short term funds are used to a very high degree to finance current and fixed assets, such management approaches indicates that a policy ultimately was characterized by low interest rates. More so, it was important to note that risk associated with short term debt was higher than long term debt. Such applications are mostly to firms operating in stable Economies that were quite certain about future cash flows. In the study by Osazee and Anao (1989) on Working capital management, resulting expression was that working capital management was a connecting rod that could affect liquidity and profitability of any firm. However, there was a trade-off between liquidity and profitability of a firm. A firm needed profitability to achieve growth and success. A firm also required some measure of liquidity to avert insolvency and liquidation problem.

Jose, Lancaster, and Stevens (1996) suggested that when managing cash conversion cycle, one could note a balance maintained between liquidity and profitability, hence there existed a trade off between liquidity and profitability, more so it was mentioned that an aggressive approach to liquidity management would result in a lower cash conversion cycle because inventory period would be reduced, accounts receivables period would be reduced, and accounts payables period would be increased. According to above foresaid scholars, more passive approach to liquidity management meant inventory and receivables periods would increase and hence payables period would decrease. A lower cash conversion cycle preserves firm's debt capacity since less short term borrowing was required to provide liquidity. A higher cash conversion cycle meant that more financing was required for inventory and receivables. Taking into account longer cash conversion cycle implied a company was more committed to cash and non-cash current assets and considerably such a firm was not as able to finance investments in cash and non-cash current assets with current liabilities (Richards \& Laughlin, 1980). Such conditions availed consequences for a company faced and hence a given firm would not be as flexible in managing cash flows. A firm having too much inventory or too many outstanding receivables implied cash flow would not be available for a company to maintain payables or other current debt. If there were high levels of inventory and large amounts of receivables outstanding than cash inflows a company receives, a company might not have enough to pay off current obligations (Miller, 2008)

\section{Conceptual Framework}

The conceptual framework was developed from literature review and it was to shed light on methodology that was used in the study. In order hold new and existing knowledge together, there should be a theory to provide conceptual framework so that knowledge can be interpreted for empirical application in comprehensive manner.

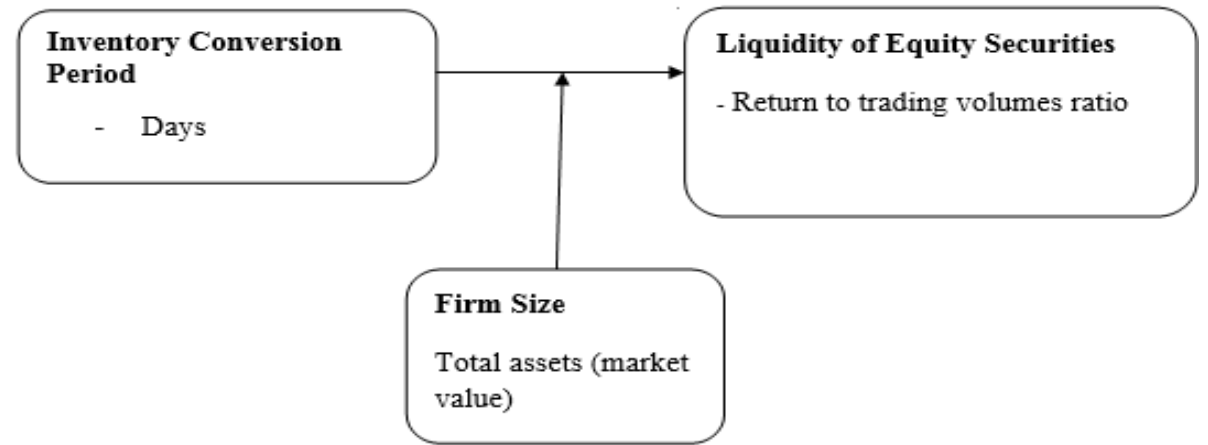

Independent Variable

Controlling Variable

Dependent Variable

Figure2.1: Conceptual-Framework

\section{RESEARCH METHODOLOGY}

Research Design

Research design was a plan, structured examination conceived so as to obtain answers to research questions and to control variance (Kerlinger, 1973). Research design stipulated arrangement of conditions for collection and analysis of data in a manner that seek to put together relevance to research objectives with an economy in procedure (Kothar, 2004). It was an overall plan on how researchers would answer their research question and meet objectives (Saunders, 2009). In the study by Srivastava and Rego (2011) on business research methodology, research design was a comprehensive plan of sequence of operations that a researcher intends to carry out to achieve the objectives of a research study. 
This study adopted a descriptive survey research design since data involved was quantitative in nature and more so descriptive study focuses on explaining situations. This study tested different variables relationship with descriptive statistics in order to establish variables relationships. As regards research philosophy it was vital to state assumptions on philosophical views under confirmation of epistemology and ontology understanding.

This study employed an ontological research philosophy paradigm with positivist epistemological assumption since positivism advocates for application of methods of natural science to study social reality and beyond without adding value to its outcome. In the study by Mathuva (2016) on determinants of disclosure level by deposit taking saving and credit cooperative societies in Kenya, ontology was viewed as science or study of being. It dealt with studying nature of reality, which could be measured. There existed two important aspects of ontology: objectivism (or positivism) and subjectivism.

\section{Study Population}

Population was a collection of elements on which a scholar can make some inference (Cooper \& Schindler, 2011). On other hand population is referred as all items in any field of inquiry as well known as a universe (Kothar, 2004). For purpose of the study, Population refers to all companies listed at Nairobi Securities Exchange at June $30^{\text {th }}$ 2016. In total, there were 61 companies listed at Nairobi Securities Exchange as at that date.

\section{Sampling Frame and Technique}

Sampling frame is a list of elements from which a sample was actually drawn (Cooper and Schindler, 2011).Sampling frame was a list containing items from which a sample is drawn (Kothar, 2004). This study took a whole population of 61 companies at Nairobi Securities Exchange on 30 $0^{\text {th }}$ June, 2016.This study used census technique method. Method involved an exhaustive enumeration of units constituting target population (Kothari, 2004). Since a population comprised of 61 companies listed at Nairobi Securities Exchange, census of all companies was conducted.

\section{Data Collection Instruments}

This study used secondary data extracted from audited financial statements and annual reports of individual companies for 10-year period inclusive 2007-2016; hence it enabled to find out relationship between independent variables and dependent variable. Collection of data was accomplished by means of secondary data collection instrument-record survey sheet.

\section{Data Collection Procedure}

Since this study used panel data technique for ten-year period (2007-2016) to determine influence of Inventory Conversion Period and Firm Size on Liquidity of Equity Securities at Nairobi Securities Exchange, data collection was availed from downloading of published financial statements of listed companies. Using record survey sheet which was data collection instrument, information was keyed in for each firm for every year of concern, information was transferred to excel program for computation of required data that was used for analysis. This study employed E-views software for purpose of interpreting regression coefficients. More so, for ensuring that sufficient degrees of freedom in models to be estimated were available, year by year data covering ten years was collected.

\section{Data Analysis and presentation}

Data analysis included descriptive and inferential statistics and analyzed in accordance with objectives of study. Descriptive analysis was first step in analysis. Descriptive statistics was vital in establishing statistical properties of a model that was to enable selection of proper functional form of expected estimable model. Hence, this study was enabled for determination of dispersion of data which included computation of mean, maximum, minimum, standard deviation and standard error values of variables overtime. The second step involved finding correlation matrix to counter find which variables could be highly correlated in-order to avoid effects of multi-collinearity which was common in time series data. Inferential statistics on the other hand is a branch of statistics largely concerned with analysis and interpretation of data obtained from a given sample or population (Hoyle \& Ingram, 1991).

\section{Model Specification and Rationale of variables}

The choice of a model could depend on ultimate objective of analysis while considering respective exogeneity of explanatory variables (Saunders \& Thornhill, 2009).This study embraced a panel data regression using Ordinary Least Squares method, where data was pooled into a panel data set and estimated using panel data regression. Unit Root Test was done to determine the stationarity. Among the tests included; Levin, Lin and Chu test (1993), ImPeseran-Shin (1997) and Phillips-Peron (2002). Hauseman test was carried out to determine the fixed effects and random effects on the panel data. 
There was one dependent variable( $\mathrm{Y})$ which was liquidity of equity securities of companies at Nairobi Securities Exchange (L) and two independent variables $\left(\mathrm{X}_{1}\right.$, and $\mathrm{X}_{2}$, ) being $\left(\mathrm{X}_{1}(\right.$ Inventory Conversion Period), $\mathrm{X}_{2}$ (Firm Size), $\beta_{0}$ implies Beta of the company at time $t ; i=1,2 \ldots 10$ years, $\beta_{1}$. . $\beta_{2}$ implied Coefficients of different independent variables for working capital management, of companies $i$ at time $t, t$ is Time $=1,2 \ldots \ldots ., 10$ Years, $\varepsilon$ was an error term.

Hence regression equations without and including Firm Size was as follows;

Regression equation of liquidity without firm size

$\mathrm{Ln}_{-} \mathrm{L}_{\mathrm{it}}=\beta 0+\beta 1 \mathrm{Ln} \mathrm{X}_{1 \mathrm{it}}+\varepsilon_{\mathrm{it}}$

Regression equation of liquidity with firm size

Ln_Lit $=\beta 0+\beta 1$ Ln_X $X_{1 i t}+\beta 2 \operatorname{Ln}_{-} X_{2 \text { it }}+\varepsilon_{i t}$

Where;

Ln - Natural logs of the variables

L - Liquidity of equity securities of Firms at securities exchange

$\beta_{0}$ - Intercept of the model

$\beta_{1}, \beta_{2}$, regression coefficients

$\mathrm{X}_{1}$ - Inventory Conversion Period

$\mathrm{X}_{2}-$ Firm Size (market value)

$\varepsilon_{\text {it }}$. Error term

\section{RESEARCH FINDINGS AND DISCUSSIONS}

\section{Response Rate}

The study was based on a total number of 61 companies listed at Nairobi Securities Exchange as per published report of $30^{\text {th }}$ June 2016 for a period of 10 years from year 2007 to 2016 . Criterion of study was to have secondary data reports of quoted companies for a period of 10 years. 52 companies consisting of $85 \%$ embraced criterion and remaining 9 companies that consisted of $15 \%$ neither had complete records for 10 years. According to Mugenda and Mugenda (2003), recommendation was that 50\% response rate was adequate, $60 \%$ good and above $70 \%$ was very good.

\section{Descriptive Statistics}

In the study by Tronchim (2006) on introduction to validity and social research methods, embrace that descriptive analysis virtually composed the ground for every quantitative analysis.Computation of mean, median, standard deviations, Kurtosis, skewness and Jarque-Bera tests were employed. Natural logarithm of Liquidity of equity securities had mean of -0.09 and standard deviation 0.021, Inventory Conversion Period (days) and Firm Size, had mean of 4.48 and 23.33 respectively, while standard deviation of similar variables were 1.29 and 2.0 respectively. The study employed three statistical methods to test normality; skewness, Kurtosis and Jarque-Bera. Skewness was used to measure asymmetry of distribution of data whereby result expected from distribution could conform to skewness being Zero for normality. Skewness being; Ln_L (L) was positively skewed and rest of variables, Ln ICP $\left(\mathrm{X}_{1}\right)$ and Ln_Z $\left(\mathrm{X}_{2}\right)$ being negatively skewed. On simulation by use of Monte-Carlo for normality, skewness value should be less than 2 . According to results all variables were normally distributed since values are less than 2. More so Kurtosis was as well employed to measure peakedness of distribution, whereby for normality result should be equal to Zero, however variables reflected positive results with Ln_L (L) indicating $2.72 \mathrm{Ln}$ ICP $\left(\mathrm{X}_{1}\right)$ and $\mathrm{Ln} \_\mathrm{Z}\left(\mathrm{X}_{2}\right)$ respectively reflecting 5.42 and 2.42. According to Sekran and Bougie (2008), using Monte Carlo simulation, kurtosis values should be less than 6 for normal distribution hence all variables justified criterion of normality.

The study employed Jarque - Bera test which is based on sample skewness and sample kurtosis. More so, simulation was employed to determine critical values for sample sizes less than 2000 . Jarque- Bera value for $L_{n} L_{2}$ was 20.76 and Ln_ICP and Ln_Z; reflected 212.4 and 8.8 respectively. Since probability values were less than $0.05(\mathrm{P}<0.05)$, indication of data distribution was normally distributed and was accepted at $5 \%$ significance level. While applying Jarque- Bera test for normality, probability values should be less than 0.05 . it implies that normality could be rejected at 5\% significance level. Awad and AI-Ewesat (2012) applied Jarque-Bera on examination of working capital indicators with stock prices on Palestinian securities exchange market and established that the results conformed with probability $\mathrm{P}<0.05$ on testing normality and hence there was normal distribution of data.

\section{Panel Unit Root Test}

In the study by Levin, Lin and Chu (2002) on unit root tests in panel data, impression was that a unit root is a stochastic trend in a time series. A time series has stationarity if a shift in time does not cause a change in a shape of distribution, for example mean, variance and covariance have to be constant over time. This study employed multiple unit root tests for evaluation of variables stationarity; Levin Lin and Chu test (2002), IM- Peseran and Shin (2003), Augmented Dickie Fuller (1981) and Phillips-Peron (2002) on panels that were not balanced. Study 
results on unit root tests indicated no unit root on the Liquidity, Cash Conversion Period and Firm Size.

\section{Inferential Statistics}

Correlation coefficients of Inventory Conversions Period were; -0.0239 respectively signifying negative correlations with Liquidity. Correlation coefficient of Firm Size was 0.034 which signified positive correlation with Liquidity. On examining of correlation coefficients, it helps in accepting or rejecting the null hypothesis that there is no correlation between the explanatory study variables. More so degree of linear relationship between two variables under concern should have correlation ranging between +1 and -1 , implying +1 reflects a positive linear relationship between variables and -1 reflects a negative stance of correlation. In the study by Sekran and Bougie (2008), when the correlation coefficient was less than 0.9 thresholds then there was no alarm of multi-collinearity.

\section{Correlation Results}

Table 4.8 Correlation of Liquidity with independent variables

\begin{tabular}{cccc}
\hline & Ln_L & Ln_ICP & Ln_Z \\
Ln_L & 1.000000 & -0.0239 & 0.034158 \\
Ln_ICP & -0.0239 & 1.000000 & 0.2526 \\
Ln_Z & 0.034158 & 0.2526 & 1.000000 \\
\hline
\end{tabular}

\begin{tabular}{ll}
\hline Notations & \\
Ln_L & - Liquidity ratio (L) \\
Ln_CCP & - Inventory Conversion Period (days) \\
Ln_Z & - Firm Size \\
Ln & - Natural log of
\end{tabular}

Table 4.8 shows reflection of correlation findings of variables of the study. Correlation coefficients of Inventory conversion and Firm Size with Liquidity were -0.0239 and 0.034158 respectively. On examining of correlation coefficients, it helps in accepting or rejecting the null hypothesis that there is no correlation between the explanatory study variables. More so degree of linear relationship between two variables under concern should have correlation ranging between +1 and -1 , implying +1 reflects a positive linear relationship between variables and -1 reflects a negative stance of correlation. In the study by Sekran and Bougie (2008), when the correlation coefficient was less than 0.9 thresholds then there was no alarm of multi-collinearity.

\section{Regression Results for Secondary Data}

Accordingly Chi-square test statistic was 13.632936 with a significant probability value of 0.0181 which was significant at 5 percent level of significance, as well since probability of 0.0181 was less than 0.05 ; it was permissible to employ fixed effects model to the panel data. This therefore meant that null hypothesis was rejected in favor of fixed effects model. Therefore, we accept fixed effects model as suitable for this study when firm size is included in a model. 
Panel regression equation (Company Size included)

Table 4.10

Dependent Variable: Ln L

Method: Panel Least Squares

\begin{tabular}{lllll}
\hline \hline Variable & Coefficient & Std. Error & t-Statistic & Prob. \\
\hline \hline Ln_ICP & 0.002994 & 0.002298 & 1.302890 & 0.0235 \\
Ln_Z & 0.005592 & 0.002351 & 2.378362 & 0.0180 \\
C & -0.189613 & 0.055879 & -3.393307 & 0.0008 \\
\hline \hline
\end{tabular}

Effects Specification

Cross-section fixed (dummy variables)

\begin{tabular}{llll}
\hline \hline R-squared & 0.099492 & Mean dependent var & -0.089932 \\
Adjusted R-squared & -0.055672 & S.D. dependent var & 0.020803 \\
S.E. of regression & 0.021374 & Akaike info criterion & -4.716467 \\
Sum squared residual & 0.148473 & Schwarz criterion & -4.127752 \\
Log likelihood & 957.8452 & Hannan-Quinn criter. & -4.482910 \\
F-statistic & 3.641204 & Durbin-Watson stat & 2.226066 \\
Probability (F-statistic) & 0.037696 & & \\
\hline \hline
\end{tabular}
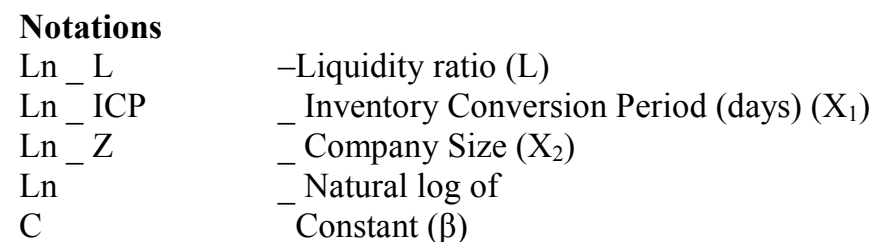

Constant $C(\beta)$ had a coefficient of -0.189613 and a significant probability value of 0.0008 which is less than 0.05 at $5 \%$ significant level. Standard error was 0.055879 , t-statistics -3.393307 . This meant that jointly these proxies influenced Liquidity during the period of study. Regression of liquidity (L) on independent variables; Inventory Conversion Period (days) and including Company Size was as follows:

$\mathrm{L}=-0.189613+0.002994 \mathrm{X}_{1}+0.005592 \mathrm{X}_{2}$

\section{Liquidity and Inventory Conversion Period}

Null hypothesis $\mathrm{H}_{01}$ : Inventory Conversion Period has no significant influence on Liquidity of Equity Securities at Nairobi Securities Exchange

Inventory Conversions Period had a coefficient of 0.002994 and significant probability value of 0.0235 at $5 \%$ level of significance. The analysis had standard error of 0.002298 , t-statistics of 1.302890 and R-square of 0.099492. This meant that Inventory Conversion Period had significant effect on Liquidity during the study period and hence it implied that when Inventory Conversion Period increased by 0.002994 percent per year then Liquidity increased by 1 percent in the same year considering other factors being held constant .In the study by Awad and AI-Ewesat (2012) on impact of Working Capital Management on prices of stocks at Palestinian stock exchange, the finding of the research was that the components of Working Capital Management had an impact on prices, hence liquidity as well.

\section{Liquidity and Firm Size}

Null hypothesis $\mathrm{H}_{02}$ : Firm Size has no significant influence on Liquidity of Equity Securities at Nairobi Securities Exchange.

Firm size had a coefficient of 0.005592 and a significant probability value of 0.0180 which is significant at 5 percent level of significance. Standard error was .002351 and t-statistics 2.378362 . This meant that when firm size increased by 0.0056 percent per year then Liquidity increased by 1 percent in same year considering holding other factors constant. Quite a number of scholars namely; Weinraub and Visscher (1998), Afza and Nasir(2007), Awad and AI-Ewesat (2012) and Sabris's (2012) on the study of working capital management of listed companies, findings embraced size of company market values had positive significant correlation with liquidity. 


\section{SUMMARY, CONCLUSIONS AND RECOMMENDATIONS \\ Summary of the Findings}

The essence of study was to determine significant influence of Inventory Conversion Period on Liquidity of Equity Securities at Nairobi Securities Exchange. The study took into consideration relevant theoretical and empirical literature correlated on dependent and independent variables. Understanding variables lead to inception of construction of conceptual framework that conceptualized independent and dependent variables. Quantitative analytical relationship among variables was found by employing E-views software.

Considering objective of the study, research relied on secondary data information in achieving what was required in the study. Ten years Panel data of individual firms was obtained from financial statements of listed companies and supported by information from Nairobi Securities Exchange especially data regarding Liquidity of Equity Securities for the period 2007 to 2016. Performance indicators for independent variables were days and for dependent variable was liquidity ratio computed by use of Amihud (2002) illiquidity model. Fixed effects model was recommended after Hausman test on consideration of independent variables inclusive controlling variable. Inventory Conversion Period influence on Liquidity of Equity Securities

This study was to determine influence of Inventory Conversion Period on Liquidity of Equity Securities at Nairobi Securities Market. However, Inventory Conversion Period had a positive significant coefficient and more so, there was a significant probability value which meant that an increase in Inventory Conversion Period had a significant effect on Liquidity of Equity Securities at Nairobi Securities Exchange; hence the rejection of the hypothesis that stated Inventory Conversion Period will not lead to Liquidity of Equity Securities of Companies at Nairobi Securities Exchange.

Firm Size (control effects) on Liquidity of Equity Securities

This study determined the influence of Firm Size on Liquidity of Equity Securities at Nairobi Securities Market. Findings of panel data correlation results indicated significant relationship of Firm Size to Liquidity, though no multi-collinearity in the data. However, Firm Size had a positive significant coefficient which meant that a decrease or increase in Firm Size had a significant effect on Liquidity of Equity Securities at Nairobi Securities Exchange; hence the rejection of the hypothesis that Firm Size would not lead to Liquidity of Equity Securities of Companies at Nairobi Securities Exchange.

\section{Conclusion}

Inventory Conversion Period influence on Liquidity of Equity Securities

Inventory Conversion Period meant how long inventory would take to be converted into cash which included all components of working capital management periods, Accounts Payables Conversion Period, Accounts Receivables Conversion Period and Inventory Conversion Period. Management required skills to balance out periods of conversion. Inventory Conversion Period refers to the time- period it takes to realize cash from the stock. According to this study Inventory Conversion Period had a significant effect on Liquidity of Equity Securities at Nairobi Securities Exchange. It meant that an increase in inventory Conversion Period led to an increase in Liquidity of Equity Securities at Nairobi Securities Exchange.

\section{Firm Size (control effects) on Liquidity of Equity Securities}

Firm Size meant market value of individual firms quoted at securities exchange market. Nairobi Securities Exchange market comprises of small, medium and large companies. Huge companies are known to command and control market by involving trading in block and large transactions. Hence this study found that Firm Size had a positive significant influence on Liquidity of Equity Securities at Nairobi Securities Exchange. Reason being with more transactions, a given firm could command securities market and hence with such a volume of equity securities on market, Liquidity at securities market is enhanced. Movement of information on large blocks of equity securities moves faster among investors and hence liquidity of securities.

\section{Areas for Further Research}

The study investigated relationship between Inventory Conversion Period and Liquidity of Equity Securities at Nairobi Securities Exchange. However, believing that this relationship could be investigated in different ways, through confirming the study results, possible presenting of different results of similar study. Hence this study presented few suggestions for what future researchers could investigate;

It could be interesting and appreciative if same population could be investigated using different statistical tests to see whether results could be the same or not. Furthermore population taken included all listed companies at Nairobi Securities Exchange, researchers could have tests done under different functional classification of companies and not taking all companies grouped together.

It could also be interesting to conduct a quantitative study around Inventory Conversion Period policies and various performance indicators at Nairobi Securities Exchange as well have in depth interviews with management of companies. This could help increasing knowledge about Inventory Conversion Period and liquidity of Equity 
Securities at securities market. As well this could assist contributors of funds, investors, analysts and managers of various companies have more knowledge about company management and securities markets.

\section{REFFERENCES}

Abubakar,Y., Jagongo, A., Almadi, O.\& Muktar, B., (2014). Effects of 2008 Global liquidity crisis on performance of banks' shares traded in Nigeria stock exchange market. African journal of Business Management, 8 (23), 1094-1100.

Aduda, O. J. (2010). Market reaction to stock splits empirical evidence from the NSE. African Journal of Business \& Management (AJBUMA). 1.

Aduda,J., Wandabwa, G.\& Onsongo,E.N.(2012).Corporate Governance Practices And Relationship between Corporate Governance and Financial Performance among Broadcasting Stations in Kenya. African Journal of Business and Management, (2), 65-84.

Appiah-Kusi, J.,\& Menyah, K. (2003). Return predictability in African stock markets. Review of Financial Economics, 12(3), 247-270.

Award, I. M. \& Al-Ewesat, A. R. ,(2012). Toward Efficient Management of Working Capital: The Case of Palestinian Exchange. Journal of Applied Finance and Banking, 2 (1), 225-246.

Al -Shubiri, F.N. \& Mohammad, A., (2013). Relation between cash conversion cycle and financial characteristics of industrial sectors: An empirical study, Investment Management and Financial Innovation, 10 (4), 95-102.

Amarjit, G., Nahum, B., \& Neil, M. (2010). The relationship between working capital management and profitability: Evidence from the United States. Journal of Business and Economics, (10) 1-9.

Amihud, Y. \& Mendelson, H. (1986). Asset pricing and the bid-ask spread. Journal of Financial Economics, (17), $223-249$.

Amihud, Y. (2002). Illiquidity and stock returns: cross-section and time series effects.Journal of financial markets, $5(1), 31-56$.

Anand, S., (2001). Review of Financial Studies, Oxford University Press, 21, 1907

Arnold, G. (2008). Corporate financial management, Fourth edition; Pearson Education Limited.

Appuhami, B.A. (2008).The impact of firm capital expenditure on working capital Management: Empirical study a cross industries in Thailand. International Management Review, 1 (4) 8-21.

Aurangazeb, A. (2012).Factors affecting performance of stock market: Evidence from Asian countries. International Journal of Academic Research in Business and Social Sciences,2(9), ISSN 2222-6990.

Belt, B., (2009).Working Capital Policy and Liquidity in the small businesses. Journal Of Small Business management, 17 (3), 43-51.

Bernstein, P.L. (1987). Liquidity, stock markets, and market makers. Financial Management, 16 (2), 54-62.

Bogdan,S., Baresa, S. \& Ivanovic,S., (2012). Measuring liquidity on stock market, Impact on liquidity ratio. Journal of Tourism and Hospitality management, 18 (2), 183-193.

Bruno,V.\& Shin, H.S., (2012). Capital flows and the risk-taking channel of monetary Policy, Mimeo Princeton University.

Bratland, E.\& Hornbrinck, J., (2013).Empirical study of relationship between working Capital policies and stock performance in Sweden, Umea, degree project, 30 ECTS.

Chatterji , S.(2010), "Impact of working capital management on profitability of the listed Companies on London Stock Exchange" Working paper series, SSRN.

Chudik, A \& Fratzscher, M.,(2011). Identifying the global transmission of the 2007-2009: Financial crisis in a GVAR model, European Economic Review 55, 325-339.

Ciccarelli, M., Maddaloni, A.\&Peydró, J.,(2010). Trusting the Bankers: A New Look at the Credit Channel of Monetary Policy. ECB Working Paper, 1228.

Cooper, R. D.\& Schindler, P.S., (2011).Business Research Methods, New Delhi: Tata Mcgraw- Hill.

Cornett, M. \& Nofsinger, J., (2009).Finance Applications and Theory. New York, Mcgraw- Hill / Irwin.

Copeland, T.E. (1976). A model of asset trading under the assumption of sequential information arrival. Journal of Finance 31, 1149-1168.

CIMA Report (2010). Global manufacturing sector current issues.

CMA Report (2014). Annual Bulletin.

Dickey.D.A.,\& Pantula. S.(1987).Determining the order of differencing in autogressive procces. Journal of Business and Economic statistics Vol.5 (455-461)

Eickmeier, S., Gambacorta, L.\& Hofmann, B., (2014). Understanding global liquidity.European Economic Review, $68,(1-18)$.

Eljelly, A. (2004). "Liquidity-Profitability Tradeoff", empirical investigation in an emerging Market". International Journal of Commerce \& Management, 14 (2), 48-61.

Filbeck, G. \& Krueger,M., (2005). Analysis of Working Capital Management, Mid-American Journal of Business, 20 (2), 11-18. 
Garson, D. G., (2012). Testing Statistical Assumptions, Asheboro: Statistical Associates Publishing Blue Book Series.

Garcia-Teruel PJ, \& Martinez-Solano. P.M., (2007). Effects of working capital management on SME profitability. International Journal of Managerial Finance,(3)164-177.

Gabrielsen, A., Marzo, M. \& Zagaglia, P., (2011).Measuring Market Liquidity, an introductory survey, SSRN 1976149.

Gamze, Ahmet \& Emi (2012), "Effects of working capital management on firms' performance Turkey". International journal of economics and financial issues vol. 2(4), 488-495

Hofmann, E. \& Kotzab, H., (2010). Supply Chain-Oriented Approach of Working Capital Management, Journal of business and logistics, 31 (2) 305-330

Horne, J., \& Wachowitz. J. (1998), "Fundamentals of Financial Management", (10th ed). Prentice-Hall International, Inc., New Jersey.

Horngren, T., Sundem ,. G, Elliot, J., \& Philbrick, D. (2012). Introduction to Financial Accounting .Tenth Edition: Pearson Education limited, Kendallville United States.

Hui, B. \& Heubel, B.,(1984). Comparative liquidity Advantages among Major U.S Stock Markets, Lexington, MA, Data Resources, Inc

Hussain, A. Farooz, S. U. \& Khan, K.U., (2012). Aggressiveness and Conservativeness of Working Capital: a Case of Pakistan Manufacturing Sector. European Journal of Scientific Research, 73 (2), 171-182.

Im, Pesaran, K. \& Shin, Y., (2003).Testing for unit roots in hetero- geneous panels.Journal of Econometrics, 115, 53-74.

Jaroslava. H \& Martin.W.,(2005).The performance of panel unit root and stationarity tests ; results from a large scale simulation. Journal of Econometric Review, 25(1)

Joshi, S., Sood, A.D., Soans, N., Denfeld, Z.,Mitra, S.S.\& Harp, G. (2008).Emerging Economies report, Centre for Knowledge Societies.

Karkowska, R. (2015). Global liquidity determinants across emerging and advanced countries. Journal of banking and financial economics, 1 (3), 152-170.

Kaddumi, T. A.\& Ramadan, I. Z. (2012). Profitability and Working Capital Management: The Jordan Case. International Journal of Economics and Finance, 4 (4), 217-226.

Kerlinger, F.N., (1973). Foundations of Behavioral Research. New Delhi: Surjeet Publications.

Kothari, C. K., (2004). Research Methodology, Methods and Technique, New Delhi: New Age International Limited Publishers.

Kumar, G. \& Misra, A., (2015). Closer view at the stock market liquidity, Asian Journal of Finance and Accounting, 7 (2)

kumar, S.G., (2009) "Behaviour of Stock Return in Size and Market-to-Book Ratio -Evidence from selected Indian Industries", International Research Journal of Finance and Economics, pp 143-153.

Kyle,A.S.,(1985).Continuous Auctions and Insider Trading. Econometrica, 53:1315-1335.

Lavrakas, P., (2008). Encyclopedia of survey research methods, 1- 2. Sage Publications, Los Angeles, United States of America.

Lazaridis, I \& Tryforidis, D., (2006). Relationship between Working Management and Profitability of Listed Companies in the Athens Stock Exchange; Journal of Financial Management and Analysis, 19 (1) 26-35.

Levin, A., Lin, C., \& Chu C., (2002). Unit root tests in panel data: Asymptotic and nite-sample properties. Journal of Econometrics, 108, 1-24.

Lettau .M.,\& Ludvigson.S.,(2001). Consumption, Aggregate wealth and Stock returns. Journal of Finance Vol vi,no.3

Maddala, G. S. \& Wu, S. (1999). 'Cross-country Growth Regressions; Problems of Heterogeneity, Stability and Interpretation', forthcoming in Applied Economics.

Maradi, M., Salehi, M., \& Arianpoor, A. (2012). A comparison of working capital management of chemical and medicine listed companies in Tehran Stock Exchange. International Journal of Business and Behavioral Science, 2 (5), 62-78.

Mattes, J., (2012).Volatility dynamics in African equity markets during financial Crisis. University of Johannesburg.

Mathuva, D.,(2016). Determinants of disclosure level by deposit taking savings and credit Cooperative societies in Kenya. Phd Thesis, JKUAT.

Mathuva, D. M.,(2010). Influence of working capital management components on Corporate profitability: A survey on Kenyan listed firms. Research Journal of Business Management, 3 (1), 1-11.

Makori, D. M. \& Jagongo, A. (2013). Working Capital Management and Firm Profitability: Empirical Evidence from Manufacturing and Construction Firms listed on Nairobi Securities Exchange, Kenya. International Journal of Accounting and Taxation, 1 (1), 1-14.

Miller, C. (2008). Is it Time to Review your Credit Policy? Retrieved on October 16, 2013. 
Mugenda, M. O. \& Mugenda, A. G., (2004).Research Methods: Quantitative and Qualitative Approaches. Nairobi: ACTS Press.

Muhammad Hassani (2014), Survey of the effect of working capital policies on profitability risk.vol.3 (1), 30-36

Nairobi Securities Exchange (2012). Various Issues. Accessed May 4, 2012

Ndirangu, K.J., (2015). Effects of working capital management on profitability of Manufacturing firms in Kenya. Unpublished thesis, JKUAT.

Ngugi, R. V., Murinde \& Green, C. (2003). How have the emerging stock exchange in Africa responded to market reforms? Journal of African Business 4, 2, 89-97.

Ngugi, R. W. (2003). What defines liquidity of stock Market: KIPPRA Discussion Paper No. 29. Nairobi: Kenya Institute for Public Policy Research and Analysis

Ngumi, M.P., (2013). Effect of innovations on financial performance of Banks in Kenya. Published thesis, JKUAT.

Nkwankwo, O.\& O sho, G.S., (2010).Empirical Analysis of corporate survival and Growth: Evidence from Efficient Working Capital Management, International Journal of scholarly academic intellectual diversity, $12(1), 1-3$.

Nyarige, N. C.\& Olweny, T., (2014). Effect of working capital management on performance of firms listed at the Nairobi Securities Exchange. Economics and Finance Review, 3, (11), 01-14.

O'Hara,M. (2004).Liquidity and financial market stability. National Bank of Belgium, Working Paper 55EconomicReview, 84, 1310-1329.

Omesa, N. W., Maniagi, G. M., Musiega, D., \& Makori, G.A. (2013). Working capital management and corporate performance: Special reference to manufacturing firms on Nairobi Securities Exchange. International Journal of Innovative Research and Development, 2(9), 177-183.

Onyuma, S.O. (2009). Day-of-the-Week and Month-of-the-Year Effect on the Kenyan Market Returns. East African social science research review, Vol. XXV (2), 53-74.

Owalabi, S.A\& Alu, C. N. (2012). Effective of working capital management and Profitability. Journal of economics and financial review,2 (6), 55-67-147. Oladipupo, A. O., \& Okafor, C. A.,(2013). Relative contribution of Working Capital

Management to corporate profitability and dividend payout ratio: Evidence from Nigeria. International Journal of Business and Finance Research, 3(2), 11-20.

Panigirahi, A.K., (2014). Understanding the working capital financing strategy; a case Study of Lupin limited. Journal of management research and analysis, 1(1).

Padachi, K. \&Carole, H.(2014). Focus on working capital management practices Among Mauritian SMEs.Journal of business management and economics,5(4), 097-108.

Padachi, K., (2006). Trends in Working Capital Management. International Review of Business Research Papers, $2(2), 45-58$

Pandey, I. M., (2008). Financial Management.(9 ${ }^{\text {th }}$ ed.). New Delhi: Vikas Publishing House Pvt. Limited.

Pastor, L. and Stambaugh, R.F. (2003). Liquidity Risk and Expected Stock Returns. Journal of Political Economy, $111,642-685$.

Phillips, P., \& Perron, P., (1988). Testing for a unit root in time series regression. Biometrika, 75, 335-346.

PWC, (2015), Global financial Markets Liquidity Study.

Petkova, R., Akbas F., Armstrong, W.J. (2011).Idiosyncratic Volatility of Liquidity and Expected Stock Returns.

Rafuse, M.E. (1996). Working Capital Management, an urgent need to refocus.Management decision, 34(2)59-63.

Rajan, R. G., \& Zingales, L. (1995). What Do We Know about Capital Structure? Some Evidence from International Data. The Journal of Finance, 50(5), 1421-1460

Raheman, A.\& Nasr, M., (2007).Working capital management and profitability-case of Pakistan firms, International Review of Business Research papers, 3(1), 279-300

Saunders, M., Lewis, P. \& Thornhill, A., (2009), Research Methods for Business Students. Fifth Edition. Financial Times: Apprentice Hall.

Saleem, Q. \& Rehman, R. U., (2011). Impact of liquidity ratios on profitability: Case of oil and gas companies in Pakistan, Interdisciplinary Journal of Research in Business, 1 (7), 95-98.

Sarr, A. \& Lybek, T., (2002).Measuring liquidity in financial markets.IMF Working Paper, WP/02/232.

Sekaran, U., (2006). Research Methods for Business: A Skill Building Approach. New York: John Wiley \& Sons, Inc.

Schilling, G. (1996).Working capital's role in maintaining corporate liquidity, TMA J, 16: 4-7

Sekaran, U., \& Bougie, (2013).Research Methods for Business: A Skill Building Approach (6th ed.). New York: John Wiley and Sons Inc.

Sharma, L. (2005).Ownership Structure and Stock Liquidity - Evidence from Indian Market .

Shin \& Soenen, L. A.,(1998).Efficiency of working capital management and corporate profitability, financial practice and education $8(2), 37-45$.

Smyth, R., (2004). Exploring the usefulness of a conceptual framework as a research tool: A researcher's reflection. 
Issues in Education Research, 14(2), 167

Strivastava, T. N. \& Rego, S., (2011). Business Research Methodology. New Delhi:Tata McGraw-Hill.

Star, P., (2008).Performance Measurements Packet.XS-IN022 REV 12/28/07JBS International inc., Aguirre Division.

Stahel, C.W., (2003).Is there a Global Liquidity Factor? Department of Finance, Fisher College of Business. Ohio State University.

Tissaoui, K. (2012). The Intraday Pattern of Trading Activity, Return Volatility and Liquidity: Evidence from the Emerging Tunisian Stock Exchange. International Journal of Economics and Finance, 4(5).

Trzcinka, C.A., Goyenko, R.Y., \& Holden, C.W., (2009). Do Liquidity Measures

Tronchim, W. M. K. (2006). Introduction to Validity, Social Research Methods.

Verbeke, G \& Lesaffre, E., (1996). A linear mixed-effects model with heterogeneity in the random-effects population. J Am Stat Assoc 1996, 91:217-221.

Weinraub, H J., \& Visscher, S. (1998). Industry Practice Relating to aggressive

conservative working capital policies. Journal of Financial and Strategic Decision, 11 (2), 11-18.

Weston, J. F. \& Copeland, T. E., (2005). Financial Theory and Corporate Policy.Boston: Pearson Addison Wesley. World Bank Report., (2012). Performance of manufacturing firms in Africa.

World Economic Forum's Global (2013).Competitive Report

Yartey,C. A.,\& Adjasi, C. K.(2007).Stock market development in sub-Saharan Africa: Critical issues and challenges. IMF Working Paper 07/209, International Monetary Fund, Washington- DC. 